\title{
The past as a work in progress
}

\author{
PATRICIA FARA*
}

\begin{abstract}
Originating as a presidential address during the seventieth birthday celebrations of the British Society for the History of Science, this essay reiterates the society's long-standing commitment to academic autonomy and international cooperation. Drawing examples from my own research into female scientists and doctors during the First World War, I explore how narratives written by historians are related to their own lives, both past and present. In particular, I consider the influences on me of my childhood reading, my experiences as a physics graduate who deliberately left the world of science, and my involvement in programmes to improve the position of women in science. In my opinion, being a historian implies being socially engaged: the BSHS and its members have a responsibility towards the future as well as the past.
\end{abstract}

Life can only be understood backwards; but it must be lived forwards.

Søren Kierkegaard, Journals and Papers, 1843

\section{Introduction}

'The past is a foreign country: they do things differently there' ${ }^{1}$ The opening sentence of L.P. Hartley's 1953 novel The Go-Between has become a historical cliché, yet like all metaphors, it imposes limitations as well as bringing insights. Contrary to its implications, the territory of the past has no independent existence, but is modified whenever a visiting historian returns and puts a different picture on display. David Lowenthal borrowed Hartley's title for his own famous book, but portrayed the past as constantly shifting territory, an endangered world plundered by souvenir-hungry historical tourists. Moreover, he insisted, during this process of repeatedly rewriting our origins, we also fashion altered versions of ourselves. ${ }^{2}$ Hartley's narrator, the elderly Leo Colston, unfolds his story chronologically as if recycling the filmed documentary of events viewed through the eyes of his younger self, to whom he has direct unimpeded access. But by the time he reaches his sixties, Colston too has become a different person. As Eric Hobsbawm remarked, autobiographers have to strip away geological deposits accrued over decades in order to 'discover and reconstruct a buried stranger' ${ }^{3}$ During the process of surveying previous eras, neither the landscape nor the raconteur has a stable identity.

\footnotetext{
* Clare College, Cambridge, CB2 1TL, UK. Email: pf10006@cam.ac.uk.

This essay is closely based on my BSHS Presidential Address at the July 2017 conference in York. I would like to thank Charlotte Sleigh and Clive Wilmer for their very helpful suggestions.

1 L.P. Hartley, The Go-Between, London: Penguin, 2004, p. 5.

2 David Lowenthal, The Past Is a Foreign Country, Cambridge: Cambridge University Press, 1985.

3 Eric J. Hobsbawm, Interesting Times: A Twentieth-Century Life, London: Allen Lane, 2002, p. 56.
} 
In his epilogue, Hartley's protagonist reflects on how the after-waves of one childhood summer had rippled through fifty years of his own life, as well as affecting younger generations provided with only a tailored version of events. This re-creation of the past was a problem pondered at the end of the nineteenth century by William Morris, the decorative artist who promoted traditional craftsmanship as part of his Ruskinian campaign against industrialization and rampant commercialism. In his introduction to a book on a medieval encyclopedia, Morris claimed that the Middle Ages were studied not by reactionaries, but by progressive modernizers. Just as individuals are moulded by their own ancestry and experiences, he insisted, so too they influence their successors through the versions of the past that they create: people intervene as active transmitters between the past and the present: 'The past is not dead, but is living in us, and will be alive in the future which we are helping to make'. ${ }^{4}$

Morris's observation points to the complexities involved when historians seek to resurrect the past. They are themselves go-betweens, inheriting preconceptions from previous eras that influence their interpretations, which in turn affect their successors. This being the case, the detached neutrality claimed by supposedly objective academic study seems an illusory and rather morally irresponsible goal. ${ }^{5}$ I prefer to regard myself as being socially engaged, using the scholarly tools at my disposal to analyse how the society in which I grew up has reached its current state, and how that information might be used to improve the lives of future generations.

In that last sentence, I deliberately switched into the first person to consider how the general problem of historical subjectivity might affect our own field. Although historians and sociologists expose the rhetorical strategies deployed by scientists to convince readers that their results are right, they often adopt and hence implicitly endorse the very style that they are analysing. Generally writing in the third person singular, they give their stories an omniscient narrative structure, thus implying that they have followed a logically ineluctable path to reach their conclusions. ${ }^{6}$ For much of the twentieth century, historians of science were predominantly former scientists, who brought to their historical writing the same language of objectivity that they had been taught in the laboratory. Moreover, given the statistics of the era, they were mainly male. But as many critics have argued, authorial gender can be significant: female biographers have challenged masculine conventions by discussing inner lives as well as public careers; moreover, until the end of the last century, professional academic history was dominated by men who had been taught to suppress gender, ethnicity and class inflections. ${ }^{7}$ Authors are inevitably intertwined with their topics: the approaches they take

4 William Morris, 'Introduction', in Robert Steele, Medieval Lore, London: E. Stock, 1893, pp. ix-xiii, xii. For a succinct summary of Morris's career see Clive Wilmer, 'Introduction', in William Morris, News from Nowhere and Other Writings, London: Penguin, 2004, pp. ix-xxvliii, ix-xiv.

5 There is, of course, a huge literature on this point, most famously (although not necessarily most helpfully), E.H. Carr's What Is History?, London: Macmillan, 1961, which was based on his 1961 lectures in Cambridge.

6 Sharon Traweek, 'Border crossings: narrative strategies in science studies and among physicists in Tsukuba Science City, Japan', in Andrew Pickering (ed.), Science as Practice and Culture, Chicago and London: The University of Chicago Press, 1992, pp. 429-65.

7 Standard texts include Paula R. Backscheider, Reflections on Biography, Oxford: Oxford University Press, 1999; Bonnie G. Smith, The Gender of History: Men, Women, and Historical Practice, Cambridge, MA and 
are affected by individual experiences, opinions and ambitions, so that seeking to eliminate themselves from their accounts is counterproductive. Interweaving personal reminiscences into a historical narrative is not narcissistic self-indulgence; rather, it makes visible that inescapable personal engagement, especially when the storyteller is old enough to have travelled through part of the foreign country under discussion.

Like many writers, when I reach the end of a book I acquire a new understanding of what I have been trying to do. After I had submitted the completed manuscript of $A$ Lab of One's Own: Science \& Suffrage in World War One (2018), I realized that it was in part an exploration of my own experiences as a female physics graduate. My favourite suffrage banner, embroidered in black and yellow, shows a female graduate in full academic dress (Figure 1). Trapped behind a locked gate with two men physiognomically depicted as 'degenerates', she despairs of ever finding the key to release her from confinement: like criminals and the insane, she has been relegated to a subordinate existence, and denied the opportunity of participating in elections. Unlike her, I have the right to vote, but that resentful feeling of captivity is one shared by many women of my generation. A Lab of One's Own focuses on the first two decades of the twentieth century, but the concluding chapters review the interwar period and how that shaped the current situation of women in STEMM subjects. Belatedly, I remembered that my mother was born in 1918, the year of the Armistice and of partial female enfranchisement, so that I had been appraising attitudes she had inherited from her own parents and then passed on to me. In turn, I must inevitably have been transmitting these to children and students, albeit in a modified form. To adapt Morris's aphorism, I had made myself into a conduit between the past and the future.

\section{A double birthday}

Such reflections on reflexivity multiplied as I contemplated preparing a presidential address for celebrating a double birthday: the fiftieth volume of the British Journal for the History of Science (BJHS), and the seventieth anniversary of the British Society for the History of Science (BSHS). In anticipation, the BJHS editor, Charlotte Sleigh, had already asked her predecessors for their favourite articles. Running from 1974 up to the present, they are reproduced in a special virtual edition. Her thought-provoking editorial introduction includes reflections by these previous editors on their selection criteria. To conclude, as if she had foreseen what I would be speaking about, Sleigh explained that for her own choice, she had picked an article displaying 'reflection concerning how our own work intersects with that of the people we study ... Onwards to the future, mes braves'. ${ }^{8}$

I have the great honour to be in a long line of presidents who have given a birthday address. The earliest was Charles Singer, who in 1948 celebrated the BSHS's first year

London: Harvard Unviersity Press, 1998; Linda Wagner-Martin, Telling Women's Lives: The New Biography, New Brunswick, NJ: Rutgers University Press, 1994.

8 See www.cambridge.org/core/journals/british-journal-for-the-history-of-science/celebrating-50-volumes, p. 179, accessed 2 October 2017. 


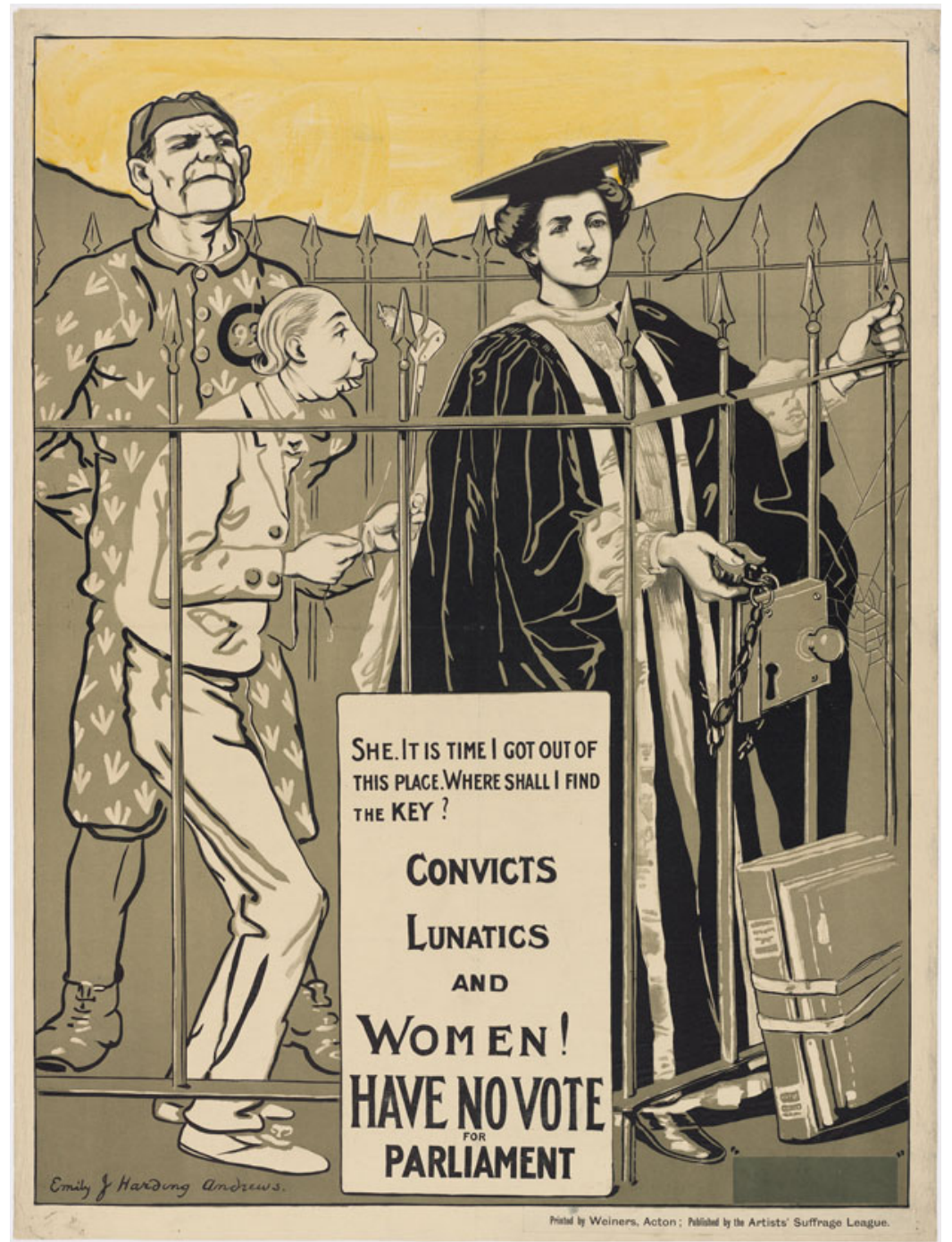

Figure 1. Convicts Lunatics and Women! by Emily Jane Harding, c.1910. Courtesy Schlesinger Library, Radcliffe Institute, Harvard University.

of existence by calling for scientific history to become a new form of humanism. In 1997, Geoffrey Cantor commemorated the society's fiftieth anniversary with a meticulously researched account of Singer's activities, describing how he had established the BSHS as part of a broader internationalist strategy that characterized his entire life. ${ }^{9}$ It was Singer who chaired the renowned second International Congress of 1931 held in

9 Charles Singer, 'The role of the history of science', BJHS (1997) 30, pp. 71-73. Geoffrey Cantor, 'Charles Singer and the early years of the British Society for the History of Science', BJHS (1997), 30, pp. 5-23. I am extremely grateful to Greg Radick for recommending these two articles. 
London, when Boris Hessen presented his Marxist analysis of Isaac Newton's Principia. And in 1948, speaking in the turmoil of post-war Europe, after the Nazi denunciation of so-called Jewish physics and the release of two atomic bombs over Japan, he declared, 'Should science cease to be international, we may know of a surety that the end of civilization is at hand'. ${ }^{10}$

Half a century later, Cantor was standing at the podium shortly after the collapse of the Iron Curtain, and he concluded his address by saying that, like Singer, he hoped the society would 'continue to play a substantial role in fostering both national and international co-operation'. ${ }^{11}$ It is therefore very fitting that in 2018, the BSHS will be hosting the biennial conference of the European Society for the History of Science in London. Many British academics are appalled by the current Brexit negotiations, and I believe it is crucial for the BSHS to maintain that policy of global integration and cooperation.

At a personal level, Cantor's discussion of Singer taught me two things about myself. For me, the first is somewhat sobering: I may possibly owe my very existence to Singer, because of the role he played in the English Jewish community caring for European refugees after 1933 - one of whom was my father. Second, as I am only a year younger than the BSHS, our histories are intertwined. Although Singer's speech had no direct impact on me, I did absorb his ideals from a young age. Like many children of my generation, I devoured the novels by Enid Blyton, who, as I now realize, gave me my earliest impressions of science.

Whatever one might think of Blyton's literary merits, the Famous Five series exerted a massive influence: sales have reached over 100 million. From her, I learnt that scientists were strange eccentric geniuses who must never be disturbed at their work. 'Doesn't your father ever go out?' asks a child; 'Scientists never do,' comes the reply. ${ }^{12}$ Moreover, a typical specimen had 'a fierce frown on his wide forehead'. ${ }^{13}$ This physiognomic reference to a wide forehead illustrates how apparently outdated ideas can acquire longevity down the generations. Blyton was impressed by a phrenologist who felt her cranial bumps when she was eight years old and correctly predicted that she would be a teacher, not a musician as her family hoped. ${ }^{14}$ So when today's children read her books, they are perhaps even absorbing ideas derived from Johann Lavater and George Combe.

Only a few months after Singer established the BSHS, Blyton published her sixth Famous Five novel, in which she articulated similar sentiments to Singer's own on scientific autonomy and internationalist ideology. Scientists should, says one of the children, 'be allowed as much freedom as they like, for their work'. ${ }^{15}$ Blyton was evidently up to

10 Singer, op. cit. (9), p. 73.

11 Cantor, op. cit. (9), p. 23.

12 Enid Blyton, The Famous Five: Five on a Treasure Island, London: Hodder Children's Books, 1942, p. 95 .

13 Blyton, op. cit. (12), p. 12.

14 Barbara Stoney, Enid Blyton: The Biography, London: Hodder \& Stoughton, 1992, pp. 32-33.

15 Enid Blyton, The Famous Five: Five on Kirrin Island Again, London: Hodder Children's Books, 1947, Chapter 2, Kindle loc. 137. 
date with scientific events. Only two years previously, the first nuclear test had been conducted on Bikini Atoll; five days after that, the first bikini swimsuit was advertised as 'the atom bomb of fashion'. ${ }^{16}$ Blyton's cover shows the tomboyish George (whose real name was Georgina) gazing through a telescope at a tall tower built by her father, Quentin Kirrin, a world-famous scientist. The children suspect that he is developing an atom bomb in his underground island laboratory, but in fact he is aiming to create a source of energy that will save the planet while bringing no financial reward for himself. 'I should give it to the whole world', he declares; 'it shall not be in the power of any one country, or collection of men'. ${ }^{17}$ The evil outsiders foiled by Blyton's children are not Germans, but businessmen.

Unsurprisingly, Blyton's scientists were male, but by creating George - most readers' favourite character - she showed little girls like me that it might be possible to escape our conventional destinies. Feminist critics deplore Blyton's gender stereotyping, but in her defence she was faithfully depicting middle-class reality at the time; I was only too familiar with genteel mummies who made cakes and looked after daddies endowed with the privilege of going out into the world every day. ${ }^{18}$ Similarly, Singer's more formal declarations of disinterested internationalism specified male scientists: 'The man of science may, better than others, claim for himself that he is a citizen of the world and that he speaks a language that can be understood by all who call themselves men'. ${ }^{19}$ Although it was then standard practice to use 'men' to denote all human beings, that does not-as I was informed immediately after giving my address - make his usage gender-neutral. The point is not that Singer was particularly biased: on the contrary, unusually for the period, in his first society council, two out of the twenty-one members were women. ${ }^{20}$ Rather, when there is an unthinking assumption of male superiority, there is no realization and hence no acknowledgement of the fact that women have been effectively obliterated from view. ${ }^{21}$ George offered hope to half the country's children that their own futures might be different.

\section{Ideal characters}

Using the label 'gender' rather than 'sex' was a politically driven innovation of the 1970 s, when the new field of 'gender studies' was regarded as a female preserve. Like many other women, I avoided it, and was reassured that I had followed the right pragmatic approach when, in the mid-1990s, a senior male academic asked me to give a lecture on the subject not because I knew about it, but because I was a woman. Determined

16 See https://en.wikipedia.org/wiki/Bikini, accessed 3 October 2017.

17 Blyton, op. cit. (15), Chapter 16, Kindle loc. 1450, original emphasis.

18 David Rudd, Enid Blyton and the Mystery of Children's Literature, Basingstoke: Macmillan Press, 2000, pp. 88-131.

19 Singer, op. cit. (9), p. 19.

20 Janet Browne, 'Officers and council members of the British Society for the History of Science, 1947-97', BJHS (1997) 30, pp. 77-89, 78.

21 For an impassioned discussion of this point with respect to ethnic prejudices in the UK see Reni EddoLodge, Why I'm No Longer Talking to White People about Race, London: Bloomsbury, 2017. 
to pre-empt any suggestion that I might be opting for girlish history, I deliberately ventured as a post-doc into a predominantly male domain: Newton.

Newton's best biography remains Never at Rest (1980) by Richard Westfall, who five years later wrote a courageous article outlining conclusions he had drawn about himself from a psychoanalytical investigation of his authorial relationship with his subject. ${ }^{22}$ Recognizing that ' $[\mathrm{b}]$ iography ... cannot avoid being a personal statement', he came to realize that it is impossible to portray another human being without displaying oneself'. Indeed, he concluded that he had done nothing less than write 'a portrait of my ideal self, of the self I would like to be'. ${ }^{23}$ As he continued his soul-searching, he accused himself of downplaying Newton's thirty years of financial and political negotiations at the Mint because he wanted to preserve unsullied Newton's reputation as an unworldly scholar. Westfall had become, he reflected, a Presbyterian elder imbued with a Puritan ethic, determined to free society of commercialization and defend academic freedom.

Around twenty years ago, reading Westfall's article prompted some self-examination of my own. Gender topics were becoming more central, and I breached my self-imposed embargo by writing about masculine role models (initially, Joseph Banks). Although I did not share his religious commitment, I did endorse Westfall's concerns about increasing commercialization and concomitant reductions in academic autonomy. Of more immediate relevance, I began to wonder how my historical research was informed by my own experience as an Oxford physics graduate as well as by my increasing involvement in campaigns to improve scientific opportunities for women. Far more recently, I have - like Westfall - gained some insight into deeper reasons for making particular narrative choices.

While writing A Lab of One's Own, at a conscious level I was aware that one of my major aims was to undermine conventional stereotypes. First World War heroes have been converted into cardboard caricatures-courageous men and nurturing women - who reflect and reinforce gendered visions of behaviour. Whereas men are commemorated for their bravery, initiative and leadership, iconic women display feminine virtues of caring and victimhood. ${ }^{24}$ The two most famous wartime examples are Edith Cavell, the nurse who sacrificed her life to rescue soldiers, and Vera Brittain, whose romanticized memoir Testament of Youth (1933) appeals to readers by simultaneously reiterating two stereotypes - the privileged yet naive young woman who volunteered for menial tasks in French hospitals, and the lovelorn faithful innocent who lost her fiancé to the patriotic cause. Even at the time, some women were sceptical. The redoubtable suffragist Mabel St Clair Stobart, who ran field hospitals in Belgium

22 Richard S. Westfall, 'Newton and his biographer', in Samuel H. Baron and Carl Pletsch (eds.), Introspection in Biography: The Biographer's Quest for Self-Awareness, Hillsdale, NJ: The Analytic Press, 1985, pp. 175-189.

23 Westfall, op. cit. (22), pp. 188, 187.

24 Gail Braybon, 'Winners or losers: women's symbolic role in the war story', in Braybon (ed.), Evidence, History and the Great War: Historians and the Impact of 1914-18, New York and Oxford: Berghahn Books, 2003, pp. 86-112; and Deborah Thom, 'Making spectaculars: museums and how we remember gender in wartime', in ibid., pp. 48-66. 
and Serbia, condemned volunteers for seeming to confirm the notion that women should be confined to subordinate caring roles. It was, she protested, 'a placebo - a bread pill, to dupe women into the belief that they are being taken seriously by the War Office ... a farce - a mere drawing-room game, conducted upon the principle that women are incapable of anything but amateur nursing' ${ }^{25}$

In contrast to the Great War's well-heeled volunteers, many thousands of women were employed in factories, transport and other conventionally male jobs. Recruitment posters and newspapers carried photographs of cheerful female labourers happily engaged in heavy engineering tasks such as repairing buses, welding components, gluing aeroplane wings or stacking large bullets, thus creating a new exemplar of the Wartime Woman Worker. But these images were mostly propaganda designed to encourage recruits and also to persuade employers that providing facilities for women was a worthwhile investment. More honest reportage would have revealed the high numbers of casualties from explosions; the day-to-day tedium of mindless, repetitive tasks; and the constant exposure to dangerous materials: 'The particles of acid land on your face $\&$ make you nearly mad, like pins $\&$ needles only much more so; $\&$ they land on your clothes $\&$ make brown specks all over them, $\&$ they rot your handkerchiefs $\&$ get up your nose $\&$ down your throat $\&$ into your eyes, so that you are blind and speechless by the time your hour is up \& you make your escape'. ${ }^{26}$

In public, tribute was paid to the munitionettes. Yet although celebratory pictures survive of jolly inter-factory football matches, there seem to be no camera records of the sick and dying. The sufferings of soldiers affected by mustard gas have come to epitomize the war's horrors, but little mention is made of the female chemical workers nicknamed Canaries because their skins went yellow and their hair went green. The ether used to make cordite was particularly damaging. 'It gives some headaches, hysteria, \& sometimes fits', a policewoman reported; 'if they stay on in the cordite sheds, they become confirmed epileptics \& have the fits even when not exposed to the fumes. Some of the girls have 12 fits or more one after the other' ${ }^{27}$ Even other women regarded the Canaries with disgust, a very different emotion from the sympathetic admiration reserved for afflicted men. Waiting for a train, the pacifist Caroline Playne remembered seeing

a sight foreign to anything civilization has ever exhibited before ... a couple of hundred dehumanized females, Amazonian beings bereft of reason or feeling, judging by the set of their faces, bereft of all charm of appearance, clothed anyhow, skin stained a yellow-brown even to the roots of their dishevelled hair. Were these really women?28

25 Quoted in Leah Leneman, In the Service of Life: The Story of Elsie Inglis and the Scottish Women's Hospitals, Edinburgh: Mercat Press, 1994, p. xi.

26 G.M. West, quoted in Angela Woollacott, On Her Their Lives Depend: Munitions Workers in the Great War, Berkeley and London: University of California Press, 1994, p. 35.

27 G.M. West, quoted in Woollacott, op. cit. (26), p. 35.

28 Caroline Playne quoted in Susan Kingsley Kent, Making Peace: The Reconstruction of Gender in Interwar Britain, Princeton, NJ: Princeton University Press, 1993, p. 37. 
Although often merely passive subjects, some women contributed to their own mythologization. The doctors Louise Anderson and Flora Murray ran a unique London hospital in Endell Street, funded by the army but staffed entirely by women and backed by suffragette organizations. When an artist was commissioned to paint the operating theatre, the pair rejected the preliminary sketch, complaining about features - a couch, sterilizing drums, a kneeling nurse - that may have represented common practice but contradicted prescribed behaviour. At their insistence, a different artist produced the official oil painting that is now displayed in the Imperial War Museum. Determined to demonstrate their professionalism, these surgeons assumed control of their own presentation by portraying a heroic but misleading vision of a calm team working in an orderly environment.

\section{Authorial identification}

After I had finished A Lab of One's Own, Westfall's article prompted me to consider more closely how and why I had picked particular women to study in greater depth. Looking back (and inwards), I can now see that, for different reasons, I was particularly committed to three of them: Ray Costelloe Strachey, Isabel Emslie Hutton and Helen Gwynne-Vaughan. Although I had not realized it at the time, my choices had been guided by priorities and preconceptions instilled in me by previous generations - not only the people I grew up with, but also the authors of the books I had read. And as Morris had suggested, in my turn I am passing on my own interpretations of these wartime lives to other readers.

Focusing on Strachey was initially an opportunistic marketing decision. She and her younger sister Karin were right at the centre of the much-picked-over Bloomsbury circle: Ray (née Costelloe) married Lytton Strachey's brother Oliver, and Karin married Virginia Woolf's brother Adrian. Yet surprisingly little has been published about them during the last thirty years - an author's gift. ${ }^{29}$ Ray Costelloe's sceptical candour about Woolf immediately appealed to me. She knew Woolf (then Stephen) before either of them was married, and they met several times. Stephen and her friends were 'a queer self-absorbed, fantastic set of people!' Costelloe wrote to her mother; 30 'They don't seem to do very much'. ${ }^{31}$ In contrast, she did an enormous amount. A leading campaigner for women's rights, she rose to prominence during the First World War - and by the time Woolf's A Room of One's Own appeared in 1929, Strachey had already published six books, including The Cause (1928), celebrated for decades as the standard history of the early suffrage movement.

29 My major biographical sources were Brian Harrison, Prudent Revolutionaries: Portraits of British Feminists between the Wars, Oxford: Clarendon Press, 1987; Barbara Strachey, Remarkable Relations: The Story of the Pearsall Smith Family, London: Gollancz, 1980; and Ray Strachey, A Quaker Grandmother, Hannah Whitall Smith, New York: Fleming H. Revell, 1914. I am also grateful for discussions with Jennifer Holmes, who in 2016 completed a PhD on Strachey.

30 LSE: 7/BSH/2/2/1, letter to her mother, Mary Costelloe, of 14 November 1909.

31 LSE: 7/BSH/2/2/2, letter to her mother of 21 December 1910. 
As I learnt more about Costelloe Strachey, I realized that I empathized with her because although she had studied mathematics at Cambridge followed by engineering at Oxford, she never practised science as a career. In modern terminology, we had both leaked out of the pipeline, a model of which I am suspicious because it infers that to stop being a scientist is to have failed in life. I also identified with her desire to organize, already evident at Cambridge, when she told her aunt, 'we have started a society which has now got more than $3 / 4$ of the college, \& which has joined with Girton \& amalgamated to the national Society ... Cambridge has become a centre of activity - meetings, debates, plays, petitions etc all through the term' ${ }^{32}$ By the time of the war, she was already high up in a suffrage union's London office, which immediately opened an employment bureau for women. Strachey played a crucial role, setting up a welding school as well as sitting on countless committees. She enthused to her mother about her swirl of activity:

I find this sort of work almost too fascinating ... Pippa [Strachey] and I have wound ourselves into the very thick of the intrigues, and we found ourselves dictating the leading article of The Times one day and sitting up until 4 a.m. preparing draft schemes for Mr Neville Chamberlain the next ... I am packed so tight with interviews that I can hardly breathe, and find myself panting from one Cabinet Minister at dinner time only to breakfast with another the next day. ${ }^{33}$

It was only after rereading Westfall's article that I began to associate Strachey with my childhood idol, Blyton's George. Strachey's two children adored her, but (or because?) she deliberately flouted conventional expectations of behaviour; from early childhood, she consistently opposed her mother's emphasis on feminine clothes, and later enjoyed fixing the family car and building her own house. Blyton was only seventeen in 1914, and I am not trying to imply that she modelled George on Strachey - but with so many women engaged in masculine roles, the war did make possible the invention of fictional girls who favoured boyish activities. Children's authors such as Blyton helped to transmit wartime values and attitudes down to the next generations: when I created my version of the past, I selected a female hero whose characteristics matched those evoked for me by Blyton.

I also came to conclude that the children's books popular among my generation guided my fascination with Hutton (then Emslie), an Edinburgh doctor funded by suffrage funds to serve in Serbia and Salonika. Although they probably did not meet face-to-face, Strachey indirectly knew about Hutton through serving on the central committee of the Scottizh organization superintending female medical teams in Eastern Europe. Lytton Strachey's niece, Ellie Rendel, salvaged a stub of pencil to send Ray first-hand information on conditions in Eastern Europe:

Our food which we brought with us consists of hard boiled eggs now 8 days old, bread of the same date $\&$ so stale that you have to cut it up with a knife $\&$ fork ... Our candles are almost finished and we have to sit in darkness most of the time ... There are swamps of dirty water

32 LSE: 7/BSH/2/2/3, letter of 24 March 1908.

33 Quoted in Harrison, op. cit. (29), p. 164, original emphasis; and Barbara Strachey, op. cit. (29), p. 273 (Ray Strachey, letter to Mary Costelloe of 4 February 1917). 
everywhere, the mud chronic, and the smells horrible. Dead horses \& dogs lie about, heaps of dirty dressings are thrown all over the station which is crowded with hospital trains. When we first arrived it was bitterly cold $\&$ snowing. ${ }^{34}$

In Britain, the centenary commemorations of the war largely ignored Emslie and her numerous colleagues on the Eastern Front, whereas in Serbia she is celebrated on stamps and by the name of a medical school. The first all-women medical team went out to Serbia in December 1914, and many of them remained in the area until March 1920, living, working and dying under appalling conditions. After a five-day arduous journey through the snow to a hospital behind the lines, Emslie found that the 'operating room was a ghastly sight, the floor swimming in blood, and pails crammed with arms and legs black with flies lay around the old deal table on which they had been amputated'. ${ }^{35}$

I uncovered conflicting opinions about Emslie. Unsurprisingly, backbiting was rife amongst women trapped together for years on end, a long way from home and persevering under terrible conditions. The (female) electrician found her 'a perfect darling ... very smart $\&$ a great sport ... we always keep smiling - whereas other members are always growling $-\&$ don't know how to make the best of things' ${ }^{36}$ In contrast, another doctor was shocked by her promotion, complaining that they 'calmly offered the position to Dr Emslie ... who is very clever \& fascinating - just a flirt - a bacteriologist no academic standing at all'. ${ }^{37}$ Such patent rivalry, expressed in effusive vocabulary, recalled the girls' boarding-school literature that I had consumed avidly after growing out of Blyton. Written by women alive during the First World War-most famously Angela Brazil - these books introduced teenage heroines who were neither sanctimonious, solitary nor victimized, but instead were welcomed into boisterous jolly gangs: they defied their teachers, enjoyed themselves and, above all, were successful on their own terms. Although old-fashioned even then, the fusion of rural adventure and rebellious independence appealed to me as a sheltered suburban schoolgirl. Fifty years later, I was similarly captivated by Emslie's wartime account, which resonated with echoes of that genre. ${ }^{38}$

From early on, I recognized that in writing about Helen Gwynne-Vaughan, I was in some ways writing about myself and the problems of identity that can be experienced by female academics. Her trajectory scarcely resembled my own: the point is not that our lives were similar, but that I too had few signposts to guide me in my career: studying physics at Oxford, working in the new field of statistical computing, being the only woman on a Cambridge committee. At various stages in her life, Gwynne-Vaughan played three contrasting roles: a wealthy aristocratic socialite, commander of the Women's Auxiliary Army Corps (WAAC) in France, and a botanist at Birkbeck

34 LSE: 7/BSH/2/2/5, letter of 26 March 1917. Isabel Emslie Hutton, With a Woman's Unit in Serbia, Salonika and Sebastopol, London: Williams, 1928.

35 Isabel Emslie Hutton, Memories of a Doctor in War and Peace, London: Heinemann, 1960, p. 166.

36 Rose West quoted in Leneman, op. cit. (25), p. 175.

37 Dr Ruth Conway quoted in Leneman, op. cit. (25), pp. 197-198.

38 Mary Cadogan and Patricia Craig, You're a Brick, Angela: A New Look at Girls' Fiction from 1839 to 1975, London: Victor Gollancz, 1976, pp. 11-262. 
College. In all three, she felt she was regarded as abnormal. Her life seems to have been a series of fights, which she mostly won, but by the end she was lonely and unhappy, as if that were the inevitable penalty of refusing to conform. ${ }^{39}$

Brought up the daughter of a wealthy international diplomat, Gwynne-Vaughan was almost twenty-one when she finally persuaded her parents to let her study zoology. This was a triple victory: in addition to her rejection of aristocratic luxury, she chose a subject deemed unsuitable for young ladies, and opted for King's College London rather than Oxbridge. Having survived the obstacle course of being a female invader in a masculine undergraduate environment, she became an assistant lecturer at Royal Holloway College. Even though that was a women-only establishment, she antagonized her colleagues by dressing too glamorously and - as she had learnt to do in her previous mode of existence - manipulating men with her charm rather than her brains. After some further career moves, she married another botanist in 1911, but immediately flouted still more rules by refusing to stop working, and instead securing for herself his former job at Birkbeck. Then followed a brief four-year period of relative happiness, until her husband died of consumption.

The First World War rescued Gwynne-Vaughan from depression. Initially, the prevailing view had been that women were unsuitable for action overseas, but by 1917 the army had realized that men could be released for fighting by deploying women to carry out routine tasks, such as cooking, driving and cleaning. By the end of the war, around 60,000 women had served in the armed forces, mostly in the WAAC. GwynneVaughan was delighted by the unanticipated invitation to head the French section of the WAAC, and immediately found herself flung into an unfamiliar type of masculine world. She spent much of her time persuading obdurate officers that her female staff were keen to work and willingly suffered hardship. As so often with women, one major focus of argument was appearance, and she became engaged in countless arguments about appropriate uniforms and insignia. For female recruits, wearing khaki symbolized their patriotic contributions to the war; yet they were constantly accused of dressing improperly and of donning uniform to disguise their true identity as prostitutes. In 1919, a journalist articulated the pent-up resentment: 'a large part of the female population of the country have had the time of their lives ... swaggering about in every kind of uniform ... [they must return to being] wives and mothers now the men are coming home'. ${ }^{40}$

Refusing to accept that domestic route, Gwynne-Vaughan returned to the Botany Department at Birkbeck, where she became professor and head of department. Again, she fitted no accepted category. An internationally renowned fungus geneticist, she

39 My main biographical sources are Helen Gwynne-Vaughan, Service with the Army, London: Hutchinson, 1942; and Molly Izzard, A Heroine in Her Time: A Life of Dame Helen Gwynne-Vaughan, 1879-1967, London: Macmillan, 1969.

40 Lucy Noakes, Women in the British Army: War and the Gentle Sex, 1907-1948, London: Routledge, 2006, pp. 1-81; Roy Terry, Women in Khaki: The Story of the British Woman Soldier, London: Columbus, 1988, pp. 32-72; Lucy Noakes, "Playing at being soldiers"? British women and military uniform in the First World War', in Jessica Meyer (ed.), British Popular Culture and the First World War, Leiden and Boston: Brill, 2008, pp. 123-145 (Saturday Review of 11 January 1919 quoted at p. 143). 
seems to have learnt from her military experiences that she might blend in by adopting male sartorial conventions and wearing a quasi-uniform of white overall and man's tie (Figure 2). Increasingly criticized for her top-down management, she oscillated between compassion and severity, displaying immense generosity towards individual students but punishing staff for minor misdemeanours. Despite receiving several academic accolades, she was gradually eased out of university committees and her splendid career fizzled out until she officially retired in 1944. Feeling herself to be the victim of repeated rejections, she turned in on herself to the point of eccentricity.

Distinguished as a scientist, as a military officer and later as a public figure, GwynneVaughan was an extraordinary woman who remained active until a few years before her death in 1967. Was she right to feel that she had been unfairly excluded from even greater success? It is difficult to know whether she was unreasonably uncooperative, or whether she was just being efficient. She may well have transgressed accepted norms of politeness for women, but on the other hand she was employed in a role that demanded masculine capabilities. Whereas a man might be admired for being authoritative, a woman behaving in the same way could (and still can) be judged authoritarian. Perhaps more than any other woman of her generation, as a scientist and a military officer Gwynne-Vaughan had ventured into two male-dominated territories, and in each one had fought her way to the top. But when she got there, she found that women as well as men resented her success.

\section{Conclusion}

Blyton was not the only influence on my childhood understanding of science and women. At school and in magazines, Marie Curie was repeatedly presented to me as a selfless martyr who dedicated her life to science. Today, she is most strongly associated with cancer and a charity for terminally ill patients, thus joining Brittain and Cavell in the long line of white-clad, saintly females caring for others. But the image of Curie that used to prevail, disseminated in texts and photographs, was of a resolutely unsentimental woman working long, lonely hours in her laboratory, and disdaining any concern for food, warmth or clothes. It is hardly surprising that girls with an aptitude for science felt ambivalent about aspiring to such a goal.

As Gwynne-Vaughan discovered, juggling conflicting expectations can be hard. In the late 1990s, an Edinburgh portrait exhibition displayed a photograph of the chemist Lesley Yellowlees standing in a laboratory wearing a bright red evening dress. Whereas a Times Higher journalist commented that she 'poses in her lab, in a ballgown, to show that one can be both feminine and a scientist', Yellowlees herself said, 'what I wanted to depict was that although I love my science there is more to life than chemistry'. ${ }^{41}$ The reporter presumably intended to pay her a compliment, but the underlying assumption of his remark is that female scientists are usually abnormally masculine. In contrast, Yellowlees depicts herself as a human being who is a good scientist, but

41 Ludmilla Jordanova, Defining Features: Scientific and Medical Portraits 1660-2000, London: National Portrait Gallery, 2000, pp. 130-134, Yellowlees quoted at 133. 


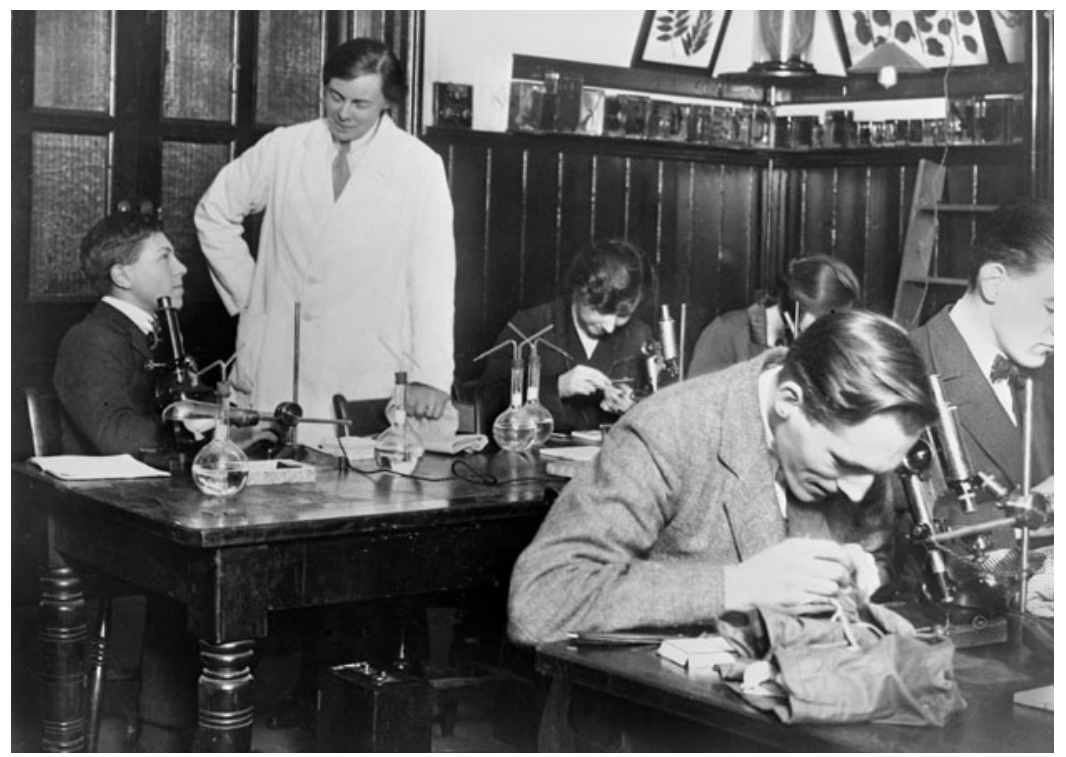

Figure 2. Helen Gwynne-Vaughan teaching botany at Birkbeck College, c.1920. @ C Birkbeck College.

on her own terms: she refuses to accept Curie's model of science as a 100 per cent commitment, because any career should be part of a broader life. Even so, she accepted the (male) photographer's suggestion that she be clothed in a grand and old-fashioned style, which would seem to undermine her passionate involvement in outreach activities - and he chose the only picture in which, untypically, she was not smiling.

Until a few years ago, I knew nothing of Strachey or Hutton or Gwynne-Vaughan, but they were just three among many female scientists - some of whom have left only fleeting traces of their existence - who helped to effect change. It remains a major concern of the BSHS to counteract inequalities in academia, whether associated with gender, ethnicity or disability. Students often despair about the current state of affairs, apparently unaware of the dramatic improvements that I- and the BSHS - have lived through. I prefer the optimism of Ray Strachey. Although she acknowledged that the 'establishment of equality of pay and opportunity for women may lie far ahead in the future', she also declared, 'that it does lie there is beyond question'. And, she continued, 'The day of economic emancipation will come, just as the day of political emancipation came. $^{42}$

The stories that historians write are inevitably and inextricably related to their own lives. In illustration, I have indicated how my own historical contributions to current debates about women in science have been affected by my experiences as an avid

42 Ray Strachey, Women's Suffrage and Women's Service: The History of the London and National Society for Women's Service, London: London and National Society for Women's Service, 1927, p. 36. 
childhood consumer of now outdated books and as a leaky pipeline scientist. But of course, my outlook has also been shaped by a myriad of other literary influences. For example, when I first finished reading George Eliot's Middlemarch in my early twenties I resolved to live by her concluding insight that even 'unhistoric acts' - small ones that seemed within my grasp - could have cumulative beneficial effects. More recently, reaching the end of Eric Hobsbawm's autobiography, I was struck by his passionate plea that '[s]ocial injustice still needs to be denounced and fought. The world will not get better on its own'. ${ }^{43}$ Both collectively and individually, Cambridge academics are often accused of retreating from the world to pursue a solitary path of esoteric scholarship. That route has never tempted me; on the contrary, I have always felt that I should take advantage of my privileged position by communicating historical research to wider audiences. For me, being a historian demands being socially engaged: the BSHS and its members have a responsibility towards the future as well as the past.

43 Hobsbawm, op. cit. (3), p. 418. 